\title{
Innovating on the Basis of Keeping Integrity and Achieving Ambitions Through Down-to-Earth Measures - The Responsibility of Art Colleges in the New Era
}

\author{
Zheng Wang* \\ China Conservatory of Music, Beijing 100101, China \\ *Corresponding author: Zheng Wang, 242421583@qq.com
}

Copyright: (C) 2022 Author(s). This is an open-access article distributed under the terms of the Creative Commons Attribution License (CC BY 4.0), permitting distribution and reproduction in any medium, provided the original work is cited.

\begin{abstract}
Since the 18th National Congress of the Communist Party of China, the world is experiencing great changes that have not been seen in centuries, and China has entered a critical period of realizing the great rejuvenation of the Chinese nation. It is of great significance to understand the profound connotation of "innovating on the basis of keeping integrity" and actively integrate as well as implement this concept into the work of art colleges and universities, so as to promote the vigorous development of the art field in China, the noble and abundant spiritual life of the people, as well as the prosperity and stability of social development.
\end{abstract}

Keywords: New era; Art colleges and universities; Aesthetic education; Innovating on the basis of keeping integrity

Online publication: January 24, 2022

\section{The profound connotation of the concept of "innovating on the basis of keeping integrity"}

\subsection{Historical implication of "innovating on the basis of keeping integrity"}

Long ago, the Chinese nation has put forward the idea of keeping integrity and innovation. As early as in the pre-Qin classics, the terms "zheng" and "xin" have appeared, in which "zheng" refers to integrity and righteousness. Confucianism emphasizes that "if the name is not right then speech will not be in order," while Taoism advocates "ruling the country with integrity. "Zheng" is not only the basic principle of cultivating morality, but also the fundamental concept of governing the country and stabilizing the country. On the other hand, "xin" means renewal, reformation, and innovation. The inscription on Shang Tang's plate stated, "If you can make things better for one day, you should make them better every day and never stop doing it." The Book of Songs and the Book of Histories of the Zhou Dynasty stated that although Zhou was an old state, its mission was to reform and "to be new people," both of which emphasize on innovation. It is mentioned in Five Bookworms that "when the world is different, things are different, and things are ready for change." Innovation and change are the inevitable requirements of the development of the times and the changes of things.

"Keeping integrity" and "innovation" are dialectically unified, indivisible, and should not be neglected. "Keeping integrity" is the promotion of righteousness, the adherence to the right path, the observance of laws, and the maintenance of truth; "innovation" is to assume a rigorous and realistic attitude, criticize and inherit the spirit, size up the situation, keep pace with the times, as well as creatively solve the current 
problems. Throughout the five thousand years of historical evolution, the Chinese nation has faced various impacts and challenges, but its fundamental source of strength has always been the same - to strive for survival and strength, self-renewal, integrity, and innovation.

\subsection{Connotation of "innovating on the basis of keeping integrity"}

Since socialism with Chinese characteristics entered a new era, the concept of "innovating on the basis of keeping integrity" has been given more connotation of the times. The concept requires the adherence to the Marxist position, viewpoint, and method in the construction of socialist modernization, the compliance to the law of social development, the assimilation of historical experience, the emphasis on the basic national conditions, being rooted in traditional culture, the change of existing things, solving of the current problems on the grounds of concept and means innovation, the constant creation of new practical and cognitive achievements which are consistent with the unity of regularity and purpose, as well as the constant exploration of a new realm for the development of Marxism in China. "Innovating on the basis of keeping integrity" is an organic combination of value orientation, development direction, and reality orientation.

\section{The natural advantage of the art field in "innovating on the basis of keeping integrity"}

Art is an indispensable part of inheriting human cultural civilization and enriching human spiritual life. Each era has its own artistic style, category, and content, with unlimited development potential. However, the artistic style of each era has internal indivisible continuity. The history of art development is not only the history of human aesthetic development, but also that of human civilization and social changes. "Innovating on the basis of keeping integrity" is an inherent feature and inevitable requirement of the development of the art field. The art field naturally has the advantage of growing in the concept of "innovating on the basis of keeping integrity."

\subsection{Art is an important way to improve personality and solidify faith}

One of the motives of art is to record and preserve valuable objects in an aesthetic way. These valuable objects include emotions, thoughts, beliefs, events, scenes, and so on. Great art can occupy the highest observation point of the human spiritual life, guide one into a state of soul through strategic exaggeration of things, as well as help one to deeply appreciate complex emotions, such as sublimity, awe, and sadness, so as to adjust the imbalance in temperament, find one's own dignity and pleasure, as well as develop in a better direction. therefore, art is an important way to improve personality and solidify faith. "Innovating on the basis of keeping integrity" in the field of art is the persistence and praise of noble and beautiful emotions with diversified artistic means ${ }^{[1]}$.

\subsection{Art is an important carrier for recording history and inheriting civilization}

Tradition is a river. Traditional art has been continuously divided, exchanged, and merged in the long river of human history, so as to form today's diverse and unified art world. Therefore, the history of art is not a constant continuation of the traditional art form, but rather a history of "transmission" and "inheritance." "Transmission" is the excavation and arrangement of traditional art and the continuation of artistic symbols; "inheritance" is the understanding and reconstruction of culture as well as the inheritance of innovation and the living state. The integrity and innovation of art are precisely reflected in the process of "transmission" and "inheritance." 


\subsection{Art is an important way to spread ideas and soften boundaries}

With the accelerated development of globalization, economic exchanges among countries around the world are becoming more and more frequent, accompanied by the intensification of conflicts between cultures and civilizations. Dealing with globalization while improving the relationship between different civilizations has become a worldwide topic. In response to this problem, Xiaotong Fei, one of the famous founders of sociology and anthropology in China, has put forward the concept of "achieving one's own goal yields gratification, but lending a hand to consummate the goal of others doubles the satisfaction; one's own goals and that of others can be unified, thus the world can be harmonized." He also called on everyone to promote the development of human culture to a higher level - the artistic realm. As an integral part of culture, art has the power of softness and firmness. The integrity and innovation in art are emphasized to respect the diversity of human cultural forms and spread cultural ideas as well as values through vivid, appropriate, and acceptable art forms, so as to enhance cultural identity, soften borders, as well as promote social harmony and world peace.

\section{Four dimensions to apply the concept of "innovating on the basis of keeping integrity"}

As the main position for cultivating art talents, prospering the art field, and enriching the spiritual and cultural life of the people, "innovating on the basis of keeping integrity" is not only the internal requirement of art colleges and universities for their own development in the art field, but also the responsibility of art colleges and universities in the new era ${ }^{[2]}$.

\subsection{Artistic creation: Profound conception, and playing a role of publicity and guidance}

Artistic creation is the first link in the development and operation of the art field. The level of artistic creation directly affects the public's aesthetic taste and social spirit.

Holding an important position for artistic creation, art colleges and universities play important roles in reflecting people's life and establishing the social spirit. $\mathrm{Ke} \mathrm{Ma}$, the former vice president of China Conservatory of Music, created more than 200 works in his life. His works such as "Naniwan," "We Workers Have Power," "The White-Haired Girl” (in cooperation with Wei Qu, Lu Zhang, Yu Xiang, etc.), and "The Marriage of Young Blacky" do not only have high artistic value, but also eulogize the great practice of the people and are still widely sung today. Beihong $\mathrm{Xu}$, the former president of the Central Academy of Fine Arts, created works such as "Put Down Your Whip" and "The Foolish Old Man Moves a Mountains," praising the Chinese people's indomitable perseverance and tenacious will to win the War of Resistance.

Social life and human practice are the inexhaustible source of artistic creation. The art creators of art colleges in the new era should always care about politics and the people, adhere to the people-centered orientation, and create works with thought, temperature, and quality to resonate with the people's hearts. It is important to adhere to the correct view of the overall situation and role, strive to tell Chinese stories well, spread the Chinese voice, carry forward the Chinese spirit, and display the Chinese image, so as to convince people with reasons, move people with emotions, and form bridges between China and foreign countries.

\subsection{Art performance: Eliminate vice, exalt virtue, and serve the people}

Artistic performance is the core of artistic activities. Art performance is neither an elite art that serves a few people, nor a performance that blindly caters to the market. It shows the excellent art works loved by the public with exquisite artistic skills and profound artistic understanding, which plays a role in leading the public and inspiring people. Such artistic performance has strong vitality. 
In the new era, teachers and students in art colleges and universities should be determined to become the vanguard of literature and art to eulogize the great practice of the people and publicize the party's principles and policies, inherit the "red gene," continue the "spiritual blood," resist the vulgar culture, and serve the people. The teachers and students of China Conservatory of Music have always been at the forefront. Operas such as the "Daughter of the Party" and songs such as the "Story of Spring," "Entering the New Era," and "Rivers and Mountains" do not only have high aesthetic value, but they are also deeply loved by the people. A group of outstanding performing artists, such as Dehai Liu, Fengzhi Jiang, and Mingyuan Liu, have devoted their lives to the development and innovation of the performance of national musical instruments and the wide dissemination of national music works, making indelible contributions to the penetration of national music into the masses and the hearts of the people.

The measure of eliminating vice, exalting virtue, and serving the people is the right path that performers in art colleges and universities in the new era should adhere to. On this basis, it is the "innovation" that performers should pursue to devote themselves to, widely learn from, and explore richer performance forms.

\subsection{Professional development: Cultural confidence, harmony, and symbiosis}

Art colleges and universities are important for cultural construction and building cultural self-confidence. Several art colleges and universities have made remarkable achievements in these fields. For example, based on Chinese music tradition and future development goals, China Conservatory of Music has put forward the 12-character school running concept of "inheriting Chinese studies, promoting national rhyme, educating national instruments, and strengthening national voice" as well as creatively reconstructed the discourse system of Chinese music schools. In order to promote the establishment, inheritance, and development of different music cultures and music schools around the world as well as the mutual understanding and exchange of music cultures in various countries, China Conservatory of Music has initiated and established the "Global Music Education Alliance," which has made great contributions to promoting the exchange and cooperation of international music education institutions and developing the cause of global music education.

Adhering to cultural self-confidence and inheriting the Chinese tradition are the fundamental footholds for the professional development of art colleges in the new era, while respecting different civilizations and promoting harmony as well as symbiosis are innovations based on integrity.

\subsection{Talent training: Pay equal attention to morality and art as well as educate people in an all-round way}

As early as the Xia, Shang, and Zhou Dynasties in China, ancient sages attached great importance to the union of morality and art. Through making rites and music, they formed a fairly flawless system of rites and music, which was popularized as the enlightenment of rites and music in morality and ethics, so as to maintain the harmony of human relations in social order. Ritual and music complement each other and constitute a complete and orderly social, political, and cultural system. Ritual and music civilization has had a significant and far-reaching impact on the history of Chinese civilization for thousands of years, and it still has strong vitality.

In the new era, cultivating talents with all-round development of morality, intelligence, body, art, and labor has become the primary goal of talent training. Teaching and educating people in art colleges is not only to teach students to master exquisite artistic skills, but also organically integrate the teaching of knowledge and skills along with the cultivation of correct outlook on life, values, and world outlook to shape their intelligence, skills, and personality as a whole ${ }^{[3]}$. China Conservatory of Music insists on building morality and cultivating people as the central link of talent training. It runs ideological and political 
work through the whole process of education and teaching, creatively promotes the construction of " $8+1$, ideological and political $+\mathrm{X}$ " curriculum system and teaching materials of music schools, closely integrates the theme of "never forget the original heart and remember the mission" with music through various curriculum forms to drive the ideological and political construction of school curriculum, as well as strives to cultivate students into artists with ideals, skills, and responsibilities.

Paying equal attention to morality and art as well as educating people in an all-round way are the fundamental principles of talent training in art colleges. On this basis, constantly exploring the effective mode of talent training is "innovation" on the basis of "integrity."

\section{Conclusion}

The development of art colleges and universities is a big system and subject, which needs the continuous exploration and adjustment of the whole society. In the new era of building a well-off society in an allround way, art colleges and universities should fully understand the profound connotation and requirements of the times, take the concept of "innovating on the basis of keeping integrity" as the fundamental guiding ideology, be grounded in tradition and determined to innovate, serve the people, be confident and inclusive, as well as make new and greater contributions to the prosperity and development of the art field as well as the happiness and stability of people's life.

\section{Disclosure statement}

The author declares that there is no conflict of interest.

\section{References}

[1] Li J, 2001, Research on Talent Training Mode of Higher Art Education, Hunan Normal University, Hunan.

[2] Guan J, 2005, "Aesthetic as the Core of Music Education" Philosophical Criticism and Cultural Philosophy Construction of Music Education. Chinese Music, 2005(04): 6-16, 30.

[3] Jin X, 2009, Aesthetic Education and Personality Cultivation of College Students, Northeast Normal University, Jilin.

Publisher's note

Bio-Byword Scientific Publishing remains neutral with regard to jurisdictional claims in published maps and institutional affiliations. 